\title{
Pengaruh Pemberian Pakan yang Berbeda Terhadap Variasi Morfologi Ikan Komet (Carassius auratus)
}

\section{Effect of Different Feed Giving on Morphological Variations in Comet Fish (Carassius auratus)}

\author{
Nailul Izzah ${ }^{1}$, Rizqi Rahmat Faizin ${ }^{1}$, Purnama ${ }^{2}$ dan Seto Sugianto Prabowo Rahardjo ${ }^{1^{*}}$ \\ ${ }^{1}$ Program Studi Budidaya Perairan, Fakultas Perikanan dan Ilmu Kelautan, Universitas Brawijaya, \\ Malang \\ ${ }^{2}$ Unit Pelaksana Teknis Pengembangan Budidaya, Pengolahan dan Pemasaran Perikanan Sempu, \\ Sleman
}

*Correspondence :

seto.wre@ub.ac.id

Received : 2019-02-03

Accepted : 2019-09-07

Kata Kunci :

Ikan komet, Pelet, Chlorella, Daphnia

Keywords :

Comet fish, Feed, Chlorella, Daphnia

\begin{abstract}
Abstrak
Ikan komet (Carassius auratus) merupakan salah satu komoditas ikan hias yang digemari masyarakat karena keindahan dan pergerakan pada tubuh yang membuat masyarakat Indonesia tertarik terhadap ikan ini. Dengan semakin banyak masyarakat yang tertarik terhadap ikan ini maka diperlukan pembenihan ikan komet yang benar. Penelitian ini bertujuan untuk mengetahui pengaruh pemberian pakan alami dan pakan buatan terhadap hatching rate (HR) dan survival rate (SR) serta morfologi ikan komet. Metode penelitian ini secara deskriptif dengan menggunakan 2 perlakuan pemberian pakan alami yaitu Chlorella sp. dengan Daphnia sp. dan pelet PF800. Hasil penelitian ini menunjukkan bahwa pemberian pakan alami (Chlorella sp.+Daphnia sp.) dan pakan pelet PF800 berpengaruh terhadap HR, SR, dan morfologi ikan komet. Perlakuan pemberian pakan pelet PF800 menunjukkan hasil terbaik yaitu HR sebesar 93,98\% dan SR sebesar 85,12\%. Hal ini dikarenakan jumlah nilai gizi pada pakan alami dan pelet PF800 sangat baik untuk pertumbuhan larva ikan komet sedangkan pakan alami memberikan warna tubuh pada ikan komet paling cerah bila dibandingkan dengan pakan pelet PF800.
\end{abstract}

\begin{abstract}
Comet fish (Carassius auratus) is one of the ornamental fish commodities favored by the community because of the beauty and movement of the body that makes Indonesian people interested in this fish. With the increasing number of people who are interested in this fish, it is necessary to hatch a correct comet seed. This study aims to determine the effect of natural feed and artificial feed on the hatching rate (HR) and survival rate (SR) and comet fish morphology. This research method is descriptive by using two treatments of natural feed, namely Chlorella sp. with Daphnia sp. and pellet PF800. The results of this study indicate that the administration of natural feed
\end{abstract}


(Chlorella sp. + Daphnia sp.) and pellet feed PF800 affect the hatching rate (HR), survival rate (SR), and comet fish morphology. Pellet PF800 feed treatment showed the best results, namely HR of $93.98 \%$ and SR of $85.12 \%$. This is because the amount of nutritional value in natural feed and PF800 pellets is perfect for the growth of comet fish larvae, while natural feed gives the brightest color of the comet's body color compared to PF800 pellet.

\section{PENDAHULUAN}

Peluang budidaya ikan dari tahun ke tahun perkembangan semakin pesat, hal ini disebabkan oleh kebutuhan masyarakat terhadap bahan pangan bergizi yang harga terjangkau meningkat. Ikan hias air tawar merupakan komoditas yang diminati karena keindahan yang meliputi bentuk dan warna sisik. Harga ikan hias relatif lebih tinggi bila dibandingkan dengan harga ikan konsumsi dan para konsumen pun rela membeli karena selain penampilan fisik yang begitu indah juga dapat menunjukkan prestise di masyarakat. Di Indonesia, telah banyak ikan hias yang berhasil dibudidayakan, salah satu adalah ikan komet (Carassius auratus auratus).

Ikan komet merupakan salah satu jenis ikan hias air tawar yang populer saat ini di kalangan pencinta ikan hias. Kelebihannya adalah warna yang indah dan lebih terang, bentuk dan gerakan yang menarik, serta mudah dipelihara dalam akuarium. Saat ini dikenal dua cara pemijahan ikan komet yaitu secara alami atau disebut juga pemijahan secara tradisional, dan pemijahan buatan yaitu menyuntik ikan dengan ekstrak kelenjar hipofisis atau biasa disebut dengan istilah induced breeding.

Perkembangan usaha budidaya ikan hias membuat para pembudidaya tergerak untuk mengoleksi ikan hiasnya, namun pada budidaya ikan hias khusus ikan komet tinggi kematian pada stadia larva. Stadia larva merupakan fase yang paling kritis dalam siklus hidup ikan (Effendi, 2009) salah satunya dikarenakan adanya penyakit (Sari et al., 2019; Khasanah et al., 2019; Riantono et al., 2019). Tingginya angka kematian tersebut menunjukkan rendahnya pertumbuhan. Pertumbuhan sangat ditentukan oleh ketersediaan pakan sebagai sumber energi untuk pertumbuhan (Affandi et al., 2009).

Adanya permasalahan yang sering dihadapi tersebut sehingga dalam pembenihan ikan komet pada pemijahan alami ini adalah membutuhkan pakan yang sesuai agar dapat menghasilkan benih ikan komet yang bagus. Pakan yang dapat digunakan yaitu berupa pakan pelet dan berupa Chlorella sp. dengan Daphnia sp. dimana keduanya memiliki tingkat gizi yang berbeda. Dengan perbedaan pemberian pakan ini diharapkan dapat membedakan pertumbuhan dan warna yang dihasilkan.

\section{METODOLOGI}

\section{Waktu dan Tempat}

Penelitian ini di lakukan pada bulan Juni 2018 di UPT Pengembangan Budidaya, Pengolahan dan Pemasaran Perikanan Sempu, Kabupaten Sleman dengan metode budidaya ikan komet yang diberi pakan berbeda yaitu pakan alami Chlorella sp.+ Dapnia sp. dan pakan buatan PF800.

\section{Materi Penelitian}

Penelitian ini menggunakan sampel berupa ikan komet, Chlorella sp., Daphnia sp., dan pelet PF800. Alat yang digunakan adalah kolam ikan, hapa, dan kakaban.

\section{Rancangan Penelitian}

Penelitian ini dilakukan dengan metode deskriptif dan pengambilan data secara langsung. 


\section{Prosedur Kerja}

\section{Persiapan Kolam}

Kolam yang digunakan untuk pemijahan yaitu kolam beton berukuran 4 x 2 m dengan kedalaman $1 \mathrm{~m}$. Pada kolam tersebut dilakukan pemasangan hapa berukuran $2 \times 1 \times 1 \mathrm{~m}$ yang nantinya akan digunakan untuk pemijahan. Kemudian dilakukan pengisian air hingga ketinggian mencapai 70 - $80 \mathrm{~cm}$. Pada dasar hapa diberi pemberat agar hapa berdiri dengan tegak. Setelah itu diberi kakaban yang terdiri dari kumpulan ijuk yang sudah diatur sedemikian rupa. Fungsi dari kakaban tersebut digunakan sebagai tempat menempel telur ikan komet. Menurut Muslim et al. (2012), kelebihan menggunakan substrat kakaban ijuk adalah bahan mudah didapatkan, tidak mudah rusak, dan tidak mengandung racun. Kelemahan menggunakan kakaban adalah bahan bersifat keras atau kasar sehingga dapat menyebabkan luka pada tubuh induk ikan komet.

\section{Pemijahan}

Teknik pemijahan alami dengan perbandingan jantan 1:1. Pemijahan secara alami yaitu pemijahan yang dilakukan secara alami dengan cara menyatukan antara induk jantan dan induk betina dalam satu kolam. Pembenihan ikan komet tidak terlalu memperhatikan musim karena pemijahan ikan komet dapat dilakukan kapan saja tanpa memperhatikan musim yang sedang berlangsung. Ikan komet pada umum akan memijah pada malam hari yaitu berkisar pukul 19.00 WIB. Induk betina akan berenang mengelilingi kolam dan diikuti oleh induk jantan. Setelah pemijahan selesai, induk diangkat dari bak pemijahan pada keesokan hari dan dapat dilakukan perhitungan fekunditas dengan pengambilan sampel pada telur ikan komet.

\section{Pemeliharaan Larva}

Larva ikan komet yang sudah berumur berkisar antara 1-2 minggu dilakukan pemberian pakan. Pada penelitian ini pakan yang digunakan menggunakan 2 jenis pakan yaitu menggunakan pelet merek MS PF800 dan Chlorella sp. dengan Daphnia sp. Perbedaan pemberian pakan ini bertujuan untuk membandingkan jenis pakan yang dapat mempercepat pertumbuhan larva ikan komet dan pakan yang menghasilkan warna lebih bagus (morfologi ikan). Perbedaan tersebut dapat dilihat dari hasil survival rate yang ada pada perlakuan tersebut. Pemberian pakan ini dilakukan hingga larva berukuran benih atau hingga larva berumur 1 bulan.

\section{Manajemen Kualitas Air}

Pengelolaan kualitas air pada kegiatan pembenihan ikan komet ini ialah dengan cara mengalirkan air secara terus menerus. Hal ini bertujuan untuk membuang feses, metabolit amonia, $\mathrm{CO}_{2}$ dan sebagainya yang dapat menjadi parasit bagi larva. Sedangkan pada hapa untuk pemijahan dilakukan pengecekan secara berkala. Hal ini bertujuan agar hapa pemijahan terhindar dari hama yang masuk ke dalam kolam. Perlu dilakukan analisa hasil untuk kualitas air agar tetap terkontrol.

\section{Analisis Data}

Data yang diperoleh berupa data kualitatif meliputi data Fertilization rate (FR), Hatching rate (HR), Survival rate (SR), dan fekunditas ikan komet (Carassius auratus).

\section{HASIL DAN PEMBAHASAN}

Hasil dari keturunan ikan komet yang dipijahkan ini menghasilkan sekitar 23.496 ekor larva. Kemudian larva dipindahkan ke tempat yang sudah disiapkan. Pada perlakuan yang pertama yaitu kolam yang sudah berisi air yang di dalam terdapat Chlorella sp. dan Daphnia sp. kemudian kolam yang lain hanya diisi air biasa. Fungsi dari Chlorella sp. dan Daphnia sp. ini berfungsi sebagai pakan alami untuk larva tersebut. Sedangkan larva yang ditempatkan pada air biasa diberi pakan pelet. Pelet yang digunakan 
merek MS PF800 dengan dibentuk pasta dengan campuran air.

Larva yang diberi pelet memiliki pertumbuhan yang lebih cepat dari pada pemberian Chlorella sp. dan Daphnia sp. salah satu faktor yang membuat larva tersebut lebih cepat pertumbuhan ialah kandungan yang ada di dalamnya. Menurut Kawaroe et al. (2009), Chlorella sp. mengandung sekitar $50 \%$ protein, lemak serta vitamin A, B, D, E dan K. Serta Daphnia sp. memiliki kandungan protein sebesar 4\%. Sedangkan pada penggunaan pelet PF800 memiliki kandungan protein sebesar 39\% - 41\%. Semakin tinggi kandungan protein yang diberikan maka semakin cepat laju pertumbuhannya. Selain itu dengan pemberian pelet bisa diberikan secara terus menerus sedangkan pada pemberian Chlorella sp. dan Daphnia sp. hanya pemberian stok pada awal penebaran saja. Sehingga di saat pakan alami tersebut mulai berkurang makan larva mulai mengalami pengurangan suplai makanan. Selain itu larva yang kekurangan suplai makanan akan menjadi kanibal.

Perubahan warna yang muncul sedikit tidak jauh berbeda antara larva yang diberi pakan antara Chlorella sp. dan Daphnia sp. dengan pelet berupa pasta. Larva yang diberi Chlorella sp. dan Daphnia sp. warna lebih mencolok dari pada larva yang berbeda perlakuannya. Hal ini bisa disebabkan larva tersebut mengalami pelambatan pada pertumbuhan namun memiliki kecepatan dalam menumbuhkan warna.

Pemberian pakan yang berbeda memiliki keunggulan dan kerugian masing-masing. Pada pemberian pakan alami cenderung warna yang dihasilkan lebih cepat dibandingkan dengan pertumbuhannya. Sedangkan pada pemberian pelet atau pakan buatan cenderung lebih mempercepat pertumbuhan. Menurut Husnan et al. (2014), pakan Moina sp memberikan warna tubuh pada ikan komet paling cerah bila dibandingkan dengan pakan buatan dan Tubifex sp. Warna tubuh ikan komet yang diberi pakan buatan lebih cerah bila bandingkan dengan pakan Tubifex sp. Ikan komet yang diberi pakan Tubifex sp. warnanya lebih memudar.

\section{Fekunditas}

Fekunditas yang didapatkan pada pemijahan induk ikan komet tersebut sebanyak 31.200 butir telur pada perlakuan pemberian pelet PF 800 dan 30.000 butir telur pada perlakuan pemberian pakan Chlorella sp dan Daphnia sp. Perhitungan menggunakan beaker glass $20 \mathrm{ml}$ dimana pada satu kali pengambilan mendapatkan sekitar 4.800 butir telur.

\section{Fertilization Rate (FR)}

FR (Fertilization Rate) atau derajat pembuahan telur adalah persentase jumlah telur yang berhasil dibuahi oleh sperma. Perhitungan FR dilakukan dengan menghitung jumlah telur yang tidak terbuahi. Telur yang tidak terbuahi akan berwarna putih susu. Jumlah telur sampel dikurangi dengan jumlah telur sampel yang tidak terbuahi, maka didapatkan hasil telur yang terbuahi. Dari hasil perhitungan FR pada larva yang diberi pakan pelet PF 800 diperoleh nilai FR $85,12 \%$. Sedangkan perhitungan FR pada larva yang diberi pakan Chlorella sp dan Daphnia sp. sebesar 80\%.

\section{Hatching Rate (HR)}

HR (Hatching Rate) atau derajat penetasan telur adalah persentase jumlah telur yang menetas. Perhitungan HR dilakukan dengan menghitung larva yang menetas keseluruhan telur. Perhitungan jumlah larva yang menetas dilakukan saat pemanenan. Dari hasil perhitungan jumlah larva yang dipanen diperoleh pada perlakuan pemberian pakan pelet PF 800 senilai HR 93,98\%. Sedangkan jumlah larva yang dipanen diperoleh pada perlakuan pemberian pakan Chlorella sp. dan Daphnia sp. senilai 88\%. 


\section{Survival Rate (SR)}

SR (Survival Rate) merupakan persentase ikan yang bertahan hidup selama masa pemeliharaan hingga panen berumur 30 hari. Sehingga hasil perhitungan SR pada perlakuan pemberian pakan pelet PF800 diperoleh sebesar 85,12\%. Sedangkan pada perlakuan pemberian Chlorella sp. dan Daphnia sp. diperoleh SR sebesar 76,99\%.

\section{KESIMPULAN}

Hasil penelitian ini dapat disimpulkan bahwa pemberian pakan pelet PF 800 terhadap larva sangat baik dibandingkan menggunakan pakan alami saja. Pemberian pakan pelet juga dapat memberikan warna yang lebih cerah pada ikan komet bila dibandingkan dengan pakan alami.

\section{DAFTAR PUSTAKA}

Affandi, R., Sjafei, D.S. and Rahardjo, M.F., 2009. Fisiologi Ikan: Pencernaan dan Penyerapan Makanan. IPB. Bogor, xii $+215 \mathrm{hlm}$. Effendi, I., 2009. Pengantar Akuakultur. 188 hal. Jakarta: Penebar Swadaya.

Husnan, M., Rusliadi, R. and Putra, I., 2014. Maintenance gold fish (carassius auratus) with different Feed on recirculation systems. Jurnal Online Mahasiswa Fakultas Perikanan dan Ilmu Kelautan Universitas Riau, 1(2), pp.1-9.

Kawaroe, M., Prartono, T., Sunuddin, A., Sari, D.W. and Augustine, D., 2009. Laju pertumbuhan spesifik chlorella sp. dan dunaliella sp. berdasarkan perbedaan nutrien dan fotoperiode. Jurnal Ilmu-Ilmu Perairan dan Perikanan Indonesia Jilid, 16(1), pp.73-77.

Khasanah, U., Sulmartiwi, L. and Triastuti, R.J., 2019. Embriogenesis dan Daya Tetas Telur Ikan Komet (Carassius auratus auratus) Pada Suhu yang Berbeda. Journal of Aquaculture and Fish Health, 5(3), pp.108-117.

Muslim, K., Wahyuningsih, S. and Setyono, B.D.H., 2012. Pengaruh
Jenis Substrat Penempel Telur Terhadap Tingkat Keberhasilan Pemijahan Ikan Komet (Carassius auratus). Jurnal Perikanan Unram, 1(1), pp.79-83.

Riantono, F., Kismiyati, K. and Sulmartiwi, L., 2019. Perubahan hematologi ikan mas komet (carassius auratus auratus) akibat infestasi argulus japonicus jantan dan argulus japonicus betina. Journal of Aquaculture and Fish Health, 5(2), pp.70-77.

Sari, P.R.E.R., Tjahjaningsih, W. and Kismiyati, K., 2019. Perubahan Histopatologi Jaringan Kulit Ikan Komet (Carassius auratus auratus) Akibat Infestasi Argulus japonicus. Journal of Aquaculture and Fish Health, 3(1), pp.27-35. 